\title{
Obituary
}

Sir Arnold Theiler, K.C.M.G.

$\mathrm{T}$ HE death of Sir Arnold Theiler on July 24 at the age of sixty-nine years has removed from our midst one of the greatest and most practical exponents of veterinary science of the century. There was no man more cosmopolitan in his principles, nor indeed was there a veterinary surgeon who was more universally welcomed in every country within whose borders he set foot, than Sir Arnold. His modest demeanour and his forceful personality, together with his untiring patience and plodding disposition, made him welcome everywhere. A Swiss by nationality and a veterinary graduate of the University of Berne, Great Britain was lucky in having him as a worker within its Colonial domains; and it was a great day for the British veterinary profession when Sir Arnold was offered-and accepted-the honorary associateship of the Royal College of Veterinary Surgeons. It was also a great honour for the Royal Veterinary College in London, when Sir Arnold made the request to Sir Frederick Hobday, its principal, that he might complete, within its walls, the summary of the great work which he had collected together on the osteo-dystrophic diseases of bone. This shortly followed his lectures (which were also given in the Royal Veterinary College, at the request of the University of London), and it was another fortunate circumstance that the editor of the English Veterinary Journal was able to secure the publication of these lectures in his journal.

Born in Switzerland in 1867, Theiler went to the Transvaal as a doctor of veterinary medicine in 1891 . $\mathrm{He}$ found the Boer farmers very difficult; their narrow ideas, which led them to think that the diseases of their cattle and sheep were punishment inflicted upon them by the Almighty, were very difficult to overcome. It was only when a severe outbreak of glanders among the horses in Pretoria, and a disastrous outbreak of rinderpest in their cattle, enabled him to demonstrate the value of scientific veterinary knowledge in checking these respective outbreaks, that his consummate patience and skill triumphed to the extent that President Kruger, realizing the great value of Theiler's help, appointed him Veterinary Surgeon to the Republic. The South African War temporarily checked his work, and, as a burgher, Theiler was appointed veterinary surgeon to the Stäats Artillery, a position which he filled with credit to himself-all the time with his brain working and learning points which stood him in good stead afterwards in his combat against disease.

Returning to Pretoria after the War, Theiler's reputation made him persona grata with the British Army staff, who were quick to recognize his knowledge and ability; and he was given laboratory facilities at Dasspoort and provided with an adequate staff. Whilst there, he came in contact with Lord
Milner and Mr. F. B. Smith, the Director of Agriculture; and eventually he was given practically a free hand, the result being the foundation of the greatest experimental veterinary laboratory in the world--at Onderstepoort. The Botha and Smuts Government gave him staunch support and, on the formation of the Union in 1910, Arnold Theiler became the first Director of Veterinary Research. In 1920 he organized the Veterinary Faculty of the University of South Africa, being appointed its first dean, a post which he held until his retirement in 1927.

Theiler's honours were many. In 1907 he had been created a C.M.G., and in 1914 the knighthood of this order became his ; then the fellowship of the Royal Society of South Africa and the first grant and medal awarded by the South African Association for the Advancement of Science. He was also the first recipient of the Scott Medal of the South African Biological Society. He was an honorary D.Sc. of the Universities of Cape Town and Syracuse, and D.Phil. of the University of Berne.

Theiler's married life - always very simple-was a happy one, and he leaves behind a widow, two sons and two daughters, all of whom are making names for themselves in the world of science. His death has left a gap which it will be very difficult to fill; but his name will ever remain not only as a pioneer, but also as a creator, in the world of veterinary science.

\section{Dr. Bernard Smith, F.R.S.}

BRITISH geology in general and the Geological Survey of Great Britain in particular have suffered a lamentable loss through the death on August 19 of Dr. Bernard Smith. Since October of last year he had served as director of the Geological Survey and Museum in succession to Sir John Flett. Smith was not only a brilliant geologist but also a scientific worker of exceptionally wide outlook, and, as he had served for thirty years on the Geological Survey in varied districts and capacities, his knowledge of the geology of Great Britain was most accurate and extensive. He had a very lovable personality, being genial and sympathetic by nature, and his sound judgment carried him successfully through many difficult situations. He died at the comparatively early age of fifty-five years, while it might have been anticipated that he had at least ten years of active work to look forward to in the Government service. Up to a few weeks ago, he was in regular attendance at his office.

Smith was born in Grantham and had his pro. liminary education at King Edward VI School there. He passed to Sydney Sussex College, Cambridge, a scholar, and graduated in the first class of the Natural Science Tripos, Parts I and II. He won the 